\title{
TRANSLATION SHIFT OF A TRANSITIVITY SYSTEM IN OBAMA AND TRUMP'S INAUGURATION SPEECH
}

\author{
Taufiq Nur Hidayat
}

\author{
taufiknurhidayat8888@gmail.com \\ Sebelas Maret University \\ Surakarta, Central Java, Indonesia
}

\begin{abstract}
The purpose of the study is to describe the process shift caused by applying certain translation techniques. The research used descriptive qualitative method by applying purposive sampling technique. The source of the data was text of Obama's and Trump's inauguration speech and its translation. There were 152 data in each inauguration speech. The data were the clause contained the process type in verbal group in English and its translation. The results of the research showed 10 data or 6.57 $\%$ in Obama's inauguration speech and 7 data or $4.60 \%$ in Trump's inauguration speech which was changing or shifting in process type from original text into target text (Indonesia). It also showed that the translation techniques caused the shift, especially in verbal group.
\end{abstract}

Keywords: modulation, transposition, implication, reduction, shift of process types

\section{INTRODUCTION}

Equivalence is the relationship between the source language and the target language (Baker, 2011). It is a severe problem in translation and influenced by the translators' competence or ability in understanding the source texts and transferring them into the target texts. Bielsa \& Bassnett (2008), Catford (1965), and Nababan (2012) also state that the fundamental problem of translation is an equivalence. More importantly, the primary aim in translation is transferring the written information from source texts into target texts by considering the same equivalence effect (Newmark, 1988).

The aforementioned argument contradicts with Nida and Taber (1982). They say that the natural equivalent of the source language message in the process of translation is influenced by two factors, meaning, and style. First, the meaning here refers to the message or information within the source language. Second, style relates to the kinds of equivalence: formal and textual equivalence (Catford, 1995). The formal equivalence uses the same word categories in the two languages, for example, a noun in source text becomes a noun in the target text. Textual equivalence, besides, consists of the same context, message, and cohesion in the two languages.

According to Baker (2011), there are two different levels of equivalence: word level and above word level. These levels are closely related to the translation process, including all different aspects of translation and hence putting together the linguistic and communicative approach. It could be simplified that equivalence in translation relates to meaning equivalence (text function) and form equivalence (grammatical structure).

Furthermore, choosing SFL as an approach is very appropriate and suitable to answer the linguistics problem either in micro or macro level (Eggins, 2004; Halliday \& Matthiessen, 2014). In systemic functional linguistics point of view, equivalence involves all aspects of social semiotics such as sociocultural context, genre, and register. The 
systemic functional theory is oriented towards language as a social process connected to a particular society and its culture which is realized by language metafunction. Systemic functional linguistics emphasizes the social function of the language used, such as its use in a community in different social contexts. From this point of view, the equivalence of the genre also includes the equivalence of social function. Then, the register equivalence includes a set of meta function equivalence consisting of discourse semantic, graphology, and lexicogrammar.

Among these three meta function equivalence, lexicogrammar is the most authentic translation technique as it is able to see a clause from the experiential meaning. According to Halliday \& Matthiessen (2014), a grammar realizing the clause structure and representing experiential ideational meaning is called as transitivity. It means that transitivity refers to the grammatical system used to express the flow of events. It focuses on the process and expressed by the paradigmatic system of process types embodied in a verb. The transitivity analysis is important to observe how people symbolize the real world and social context.

Process type is one of the elements of the transitivity system which is realized in ideational meaning (Halliday \& Matthiessen, 2014). Ideational meaning is one of the metafunction or meaning in lexicogrammar stratum. According to Santosa (2009), the equivalence of lexicogrammar should involve the assessment of the three metafunctions realized in the grammar. The inequivalence of the three meanings in the source text and target text may result in the inequivalence of meaning in general or shift in language style. Halliday and Matthiessen (2014) describe three major and three minor process types in the English language. The major process types are material, mental and relational processes. The minor process types are behavioral, verbal and existential processes. The three major process types are by far the most common and have distinct structural characteristics. The minor process types are located between the major process types in a circular model: behavioral processes are placed between mental and material processes, existential processes between material and relational processes, and verbal processes between relational and mental processes.

Regarding with all above, to be equivalent, the translators need to employ some specific translation techniques, e.g., modulation, transposition, implicitation, explicitation, and reduction. It is found that applying these techniques might cause some shifts either on a grammatical or meaning level. In some cases, the shifts might change the genuine ideas of the source text. Choosing the translation technique is shifting which is the translation will be changed either in structure or meaning, in this case, is changing in process type. The technique chosen can change the grammatical structure so that it can affect the shift of word class and the shift of both lexical and grammatical forms.

Choosing the certain verbs will influence the process in the clause, including its participants. According to Toury (2012: 80), translation always involves shifts, some of which are obligatory and others nonobligatory; obligatory shifts take place because of the systemic differences that exist between the source and the target language.

A speech is one of the texts with different language form, and the direction of the texts depends on its speakers. It can also be used as measuring tools to know someone ability in giving the influence to the audience or readers by using the opinion and people thought. Besides, it also has a role in constructing the influence. People are excited to welcome the presidential inauguration, especially in superpower country like in the USA. Therefore, translating a speech is quite challenging as it has various contexts and shifts are found many times here.

There are some previous studies conducted in the process shifts using SFL approach. Hidayah (2013), Pramuditya (2016), Purwaningsih (2010), Hill-Madsen (2014), Santosa (2009), and Sujono \& Wiratno (2016) analyzed the shift kinds in translation and its structure. Moreover, Hatim \& Munday (2013), Mardiana (2014), and He \& Wen (2015) showed that modulation and transposition are the two techniques caused the shift of translation.

This study, therefore, tries to analyze the Obama and Trump's inauguration speech in White House, Washington DC, USA. As we 
know that Obama is the first Afro-American President won the election twice, and he has a different background with Trump's. Accordingly, Trump has a business background and always controversies with his ideas. Those two famous and power people put their background knowledge into their speeches and make them very rich in contexts. By using Halliday's systemic functional framework theory, this study is conducted to find out the kinds of translation technique and the effect toward on translation shift especially in transitivity system, which have never been done before in the previous studies.

\section{METHOD}

The research employs a descriptive qualitative method by using purposive sampling technique. As it is a case study, the data are taken from the Obama and Trump's inauguration speech in White House, Washington DC, the USA in the form of documents of speech text and its translation. The data are focused on the clause contained the process type in verbal group in English and its translation. These qualitative data are obtained from content analysis, questionnaire, and in-depth interview. The validation uses source and method triangulation. In choosing the informants or validator, the research uses a criterion-based selection sampling technique. Data analysis used domain analysis, taxonomy analysis, componential analysis, and culture theme analysis (Spradley, 1980).

\section{RESULTS AND DISCUSSION}

\section{Obama Speech Translation}

There are 152 data in Obama's speech translation. From those data, it is obtained that 10 data $(0.65 \%)$ are changing from one process to another process in the target text. It does not change the meaning significantly. Based on the result above can be concluded that there are 6 kinds of shift. They are: a) 2 data $(1.32 \%)$ identifying relational process (IRP) into attributive relational process (ARP) is; b) 2 data (1.32\%) mental process (MP) into mental behavioral process (MBP); c) 2 data $(1.32 \%)$ material process into $\varnothing$ process; d) 2 data $(1.32 \%)$ attributive relational process (ARP) into attribute conflated with process; e) 1 datum (0.66\%) relational attributive into existential process ; and f) 1 datum $(0.66 \%)$ material process into attribute conflated with the process is. While the shift of translation caused by 3 translation techniques. They are: a) 4 data $(2.63 \%)$ by implicitation; b) 4 data $(2.63 \%)$ by modulation; and c) 2 data (1.32\%) by using transposition.

Table 1. Process Shift in Obama's Speech

\begin{tabular}{lllll} 
No & $\begin{array}{l}\text { Process in } \\
\text { ST }\end{array}$ & $\begin{array}{l}\text { Process in } \\
\text { TT }\end{array}$ & Freq. & $\begin{array}{l}\text { Percen } \\
\text { tage }\end{array}$ \\
\hline 1. & IRP & ARP & 2 & 1.32 \\
\hline 2. & Mental & $\begin{array}{l}\text { Mental } \\
\text { behavior }\end{array}$ & 2 & 1.32 \\
\hline 3. & Material & Ø process & 2 & 1.32 \\
\hline 4. & ARP & $\begin{array}{l}\text { Attribute } \\
\text { / process }\end{array}$ & 2 & 1.32 \\
\hline 5. & $\begin{array}{l}\text { Attribute/p } \\
\text { rocess }\end{array}$ & Existential & 1 & 0.65 \\
& Material & $\begin{array}{l}\text { Attributiv } \\
\text { e/process }\end{array}$ & 1 & \\
\hline 6. & & 10 & 0.65 \\
\hline & $\begin{array}{l}\text { Total } \\
\text { Process } \\
\text { Shift }\end{array}$ & & & \\
\hline
\end{tabular}

The shifts are caused by three techniques applied by the translator. The techniques are drawn in a table as follows:

Table 2. Translation Techniques Caused the Process Shift

\begin{tabular}{clcc}
\hline No & $\begin{array}{c}\text { The technique } \\
\text { influence the } \\
\text { shift }\end{array}$ & Frequency & Percentage \\
\hline 1 & Modulation & 4 & 2.63 \\
2 & Implicitation & 4 & 2.63 \\
3 & Transposition & 2 & 1.32 \\
\hline & Total & $\mathbf{1 0}$ & $\mathbf{6 . 5 7 \%}$ \\
\hline
\end{tabular}

Based on the table above, it can be seen that the process shift between source text and target text caused by using modulation, implicitation, and transposition technique. They are known that modulation usually used by the translator to translate the text by changing the point of view either in form or its structure. Meanwhile, implicitation is the opposite of explicitation. Explicitation expresses clearly and directly the meaning of the text. So, implicitation expresses the meaning implicitly or indirectly. It caused by the difference of language system. The use of this technique makes the meaning is easier to 
understand in the target text. The last technique which causes the shift is transposition. Transposition is used by changing the grammatical category from source text into target text. This is done because of the differences in linguistic rules between the two languages. This technique is similar to the modulation technique. The technique of transposition also has two properties: obligatory and optional. This technique can change the grammatical structure, so it can affect the shift of word class and the shift of both lexical and grammatical forms.

Based on the research finding, the technique used which is caused the process shift is transposition and modulation, implicitation, and reduction. It showed that the translator still found the difficulties in finding out the specific equivalence for the verbs in source text and target text. Sometimes, certain verb had the meaning in source text but there is no equivalence in target text. So, most of the grammatical feature changed in form but it did not change in meaning. Applying this technique can affect to the translation result because it can cause the shift neither in structure nor its semantic feature. Therefore, structure shift or class shift will be possible in translation dealing with the difference of grammatical rule.

Some process shift examples will be given in the following explanation:

Table 3. IRP in Source Text

\begin{tabular}{cl}
\hline Data & Source Text \\
\hline 089.0S.ST & $\begin{array}{l}\text { That's what will lend meaning to } \\
\text { the creed our fathers once } \\
\text { declared. }\end{array}$ \\
\hline 090.0S.ST & $\begin{array}{l}\text { That's what will lend meaning to } \\
\text { the creed our fathers once } \\
\text { declared. }\end{array}$ \\
\hline
\end{tabular}

Table 4. ARP in Target Text

\begin{tabular}{|c|c|}
\hline \multicolumn{2}{|l|}{ Data } \\
\hline 089.0S.TT & $\begin{array}{l}\text { Ini yang akan memberi arti } \\
\text { pada keyakinan yang dulu di } \\
\text { deklarasikan para pendiri } \\
\text { negara kita. }\end{array}$ \\
\hline 090.0S.TT & $\begin{array}{l}\text { Ini yang akan memberi arti } \\
\text { pada keyakinan yang dulu di } \\
\text { deklarasikan para pendiri } \\
\text { negara kita. }\end{array}$ \\
\hline
\end{tabular}

From the two examples clause above, it can be seen from the word 'that' in source text which is both participants function as a token. Both clauses in source text are reversible while both clauses in the target text are irreversible. It can be seen that the copula 'is' in two clauses was deleted or implicating in target text. So, it can be said that the translator used implicitation technique.

The implicitation technique is a translation technique by implicating the purpose or message in target text. It is chosen because of the grammatical one language with each other is different. The use of this technique is in order that the translation and the message easier to understand in the target text. This technique is the opposite of an explicit technique. This technique was chosen as a consequence because of the difference in the language system. The impact of the technique potentially causes the shift either in form or in the meaning of the text. But, it will not make the translation quality becomes inaccurate.

Table 5. MP in Source Text

\begin{tabular}{ll}
\hline Data & Source Text \\
\hline 066.0S. & $\begin{array}{l}\text { We, the people, still believe [[that } \\
\text { ST }\end{array}$ \\
& $\begin{array}{l}\text { measure of security and dignity]]. } \\
\text { 077.0S. }\end{array}$ \\
ST & $\begin{array}{l}\text { We, the people, still believe [[that our } \\
\text { obligations as Americans are not just } \\
\text { to ourselves]], but to all posterity. }\end{array}$ \\
\hline
\end{tabular}

Table 6. MBP in Target Text

\begin{tabular}{ll}
\hline Data & Target Text \\
\hline 066.0S.TT & Kita, rakyat Amerika, masih yakin \\
& [[bahwa setiap warga berhak atas \\
& keamanan dan martabat yang \\
& mendasar]]. \\
\hline 077.0S.TT & Kita, rakyat Amerika, masih yakin \\
& [[bahwa kewajiban kita sebagai \\
& orang Amerika bukan hanya untuk \\
& diri kita sendiri]], tetapi untuk \\
& semua anak cucu. \\
\hline
\end{tabular}

From both examples above, it can be seen from the verb 'believe' in source text which is translated to be an adjective 'yakin' in Bahasa Indonesia (target text). It can be seen that in the translation result occurs the shift grammatically and process. The technique used by the translator is transposition. The technique used by replacing the grammatical category from source text into target text. It 
was done because there is grammatical difference between English and Indonesia. This technique is almost similar to modulation. Transposition technique has also two characteristics. It is obligatory and optional which can change the grammatical structure. So, it will influence the category shift or class shift either lexically or grammatically and will change the process types from source language into target language.

Table 7. MP in Source Text

\begin{tabular}{ll}
\hline Data & Source Text \\
\hline 022.0 & Through blood drawn by lash and \\
S.ST & blood drawn by sword, we learned \\
& [[that no union founded on the \\
& principles of liberty and equality \\
& could survive half-slave and half- \\
& free]]. \\
\hline 023.0 & Through blood drawn by lash and \\
S.ST & blood drawn by sword, we learned \\
& [[that no union founded on the \\
& principles of liberty and equality could \\
& survive half-slave and half-free]].
\end{tabular}

Table 8. $\theta$ Process in Target Text

\begin{tabular}{ll}
\hline Data & Target Text \\
\hline 022.0S.TT & Melalui cucuran darah karena \\
& cambukan dan cucuran darah \\
& karena pedang, kita tahu [[bahwa \\
& tidak ada persatuan yang didirikan \\
& atas dasar prinsip kebebasan dan \\
& kesetaraan dapat bertahan dengan \\
& setengah-budak dan setengah \\
& bebas]]. \\
& Melalui cucuran darah karena \\
& cambukan dan cucuran darah \\
& karena pedang, kita tahu [[bahwa \\
& tidak ada persatuan yang didirikan \\
023.0S.Tas dasar prinsip kebebasan dan & kesetaraan dapat bertahan dengan \\
& setengah-budak dan setengah \\
& bebas]].
\end{tabular}

Based on the data examples above, it can be seen from the passive verb 'drawn' which is material process clause translated to be 'cucuran' which is a noun in the target language. And it has no process in target language. Indirectly, based on both examples above, the translator used the modulation in meaning as well as transposition in its shape. Actually, through blood was drawn by lash can be translated 'melalui darah yang dicucurkan'. However, in this case, the translator decided to translate to be 'melalui cucuran darah karena cambukan'. It has the meaning that the sacrifice such as blood was drawn has been done by patriots of American founder to get the independence and superiority. The translator decides to use modulation technique (obligatory) caused by the grammatical rule differences. So, the translation result takes place the changing of point of view between source texts into target text.

Table 9. ARP in Source Text

\begin{tabular}{ll}
\hline Data & Target Text \\
\hline 051.0S.ST & We are true to our creed [[when a \\
& little girl [[borninto the bleakest \\
& poverty]] knows [[that she has the \\
& same chance to succeed as anybody \\
& else]]]], because she is an \\
& American; she is free, and she is \\
& equal, not just in the eyes of God \\
& but also in our own.
\end{tabular}

Table 10. Attribute as Process in Target Text

\begin{tabular}{ll}
\hline Data & Target Text \\
\hline 051.0S.TT & Kita benar-benar patuh pada \\
& keyakinan kita [[apabila seorang \\
anak perempuan yang lahir dalam \\
kemiskinan yang parah]] tahu \\
[[bahwa ia memiliki kesempatan \\
yang sama untuk berhasil seperti \\
yang lainnya]]], karena ia adalah \\
warga Amerika, ia hidup dalam \\
kebebasan, dan ia setara, bukan \\
hanya di mata Tuhan tetapi juga \\
di mata kita.
\end{tabular}

In the example above, it can be seen in target text (Bahasa Indonesia) which do not has copula like in English has. The pronoun 'we' in the source language functions as 'token' as well as describe the US people. This type of attributive relational clause is an intensive clause that has characteristic ' $x$ ' is ' $a$ '. But, in the target language, it can be said that ' $\mathrm{x}$ ' or kita is ' $\mathrm{a}$ ' or benar-benar patuh pada keyakinan. In other words, it can't be said kita adalah benar-benar patuh pada keyakinan kita.

The copula pattern in English was influenced by the tenses; meanwhile, in Indonesia do not have a tense which refer the event. Because of the difference in language system, the copula 'are' intentionally was not translated explicitly to be 'adalah' in Bahasa 
Indonesia by the translator. If the translation of copula 'are' was forced to translate, so it will be less acceptable in target language. It is very clear that the translator used implicitation which is automatically making the translation to be shifting. Grammatically, the pattern is shifting but the meaning is not.

\section{Trump's Speech Translation}

From 152 data in Trump's speech translation, it is obtained that 10 data $(0.65 \%)$ are changing from one process to another process in target text. It does not change the meaning significantly. It can be concluded that there are 6 kinds of shift. They are: a) 1 datum $(0.65 \%)$ mental behavior process into attributive relational process; b) 1 datum $(0.65 \%)$ identifying relational process into attributive relational process; c) 1 datum $(0.65 \%)$ attributive relational process into attribute conflated with process; d) 1 datum $(0.65 \%)$ extra-causer process into attributive relational process into attribute conflated with process; e) 1 datum $(0.65 \%)$ material process into attributive relational process into attribute conflated with process; f) 1 datum $(0.65 \%)$ mental behavioral process into attribute conflated with process; g) 1 datum $(0.65 \%)$ identifying relational process into existential process is. While the shift of translation caused by 4 translation techniques. They are: a) 4 data (2.63\%) by modulation; b) 1 data $(0.65 \%)$ by implicitation; c) 1 data $(0.65 \%)$ by using explicitation; and d) 1 data $(0.65 \%)$ by reduction.

Table 11. Process Shift in Obama's Speech

\begin{tabular}{lllll}
\hline No & $\begin{array}{l}\text { Process } \\
\text { in ST }\end{array}$ & $\begin{array}{l}\text { Process in } \\
\text { TT }\end{array}$ & Freq. & $\begin{array}{l}\text { Percent } \\
\text { age }\end{array}$ \\
\hline 1. & MB & ARP & 1 & 0.65 \\
\hline 2. & IRP & ARP & 1 & 0.65 \\
\hline 3. & ARP & Att/process & 1 & 0.65 \\
\hline $\mathbf{4 .}$ & $\begin{array}{l}\text { Extra- } \\
\text { causer }\end{array}$ & ARP & 1 & 0.65 \\
\hline $\mathbf{5 .}$ & Material & ARP & 1 & 0.65 \\
\hline $\mathbf{6 .}$ & MB & Att/Process & $\mathbf{1}$ & 0.65 \\
\hline $\mathbf{7 .}$ & IRP & Existential & $\mathbf{1}$ & 0.65 \\
\hline & Total & $\mathbf{7}$ & $\mathbf{4 . 6 0}$ \\
\hline
\end{tabular}

The shifts in the speech translation above were caused by four techniques applied by the translator. The techniques are drawn in a table as follows:

Table 12. Translation Techniques Caused the Process Shift

\begin{tabular}{clcc}
\hline No & $\begin{array}{c}\text { The technique } \\
\text { influence the } \\
\text { shift }\end{array}$ & Frequency & Percentage \\
\hline 1 & Modulation & 4 & 2.63 \\
2 & Implicitation & 1 & 0.65 \\
3 & Explicitation & 1 & 0.65 \\
4 & Reduction & 1 & 0.65 \\
\hline & TOTAL & $\mathbf{7}$ & $\mathbf{4 . 6 0 \%}$ \\
\hline
\end{tabular}

The three techniques have been explained in Obama's speech above. All of them were almost same. But, in Trump's speech translation found a techniques which cause the shift also. It is reduction. This technique is used by compressing existing information on source text. So, it can be said that the reduction implicate the information to target text. This technique is done by implicating or omitting some information. Some translation process shift examples will be given in the following explanation:

Table 13. MBP in Source Text

\begin{tabular}{ll}
\hline Data & \\
\hline 021.TS.S & The establishment protected itself, \\
$\mathrm{T}$ & but not the citizens of our country.
\end{tabular}

MBP: Mental Behavioral Process; TS: Trump's Speech: ST: Source Text

Table 14 MBP in Target Text

\begin{tabular}{ll}
\hline Data & Target Text \\
\hline 066.TS. & Pembangunan negara ini dilindungi, \\
TT & tetapi hal serupa tidak dirasakan oleh \\
& warga dari negara kami.
\end{tabular}

From the example above, the verb 'protected (past participle) and there is an auxiliary verb in source text implicitly. The verb 'protected' is the process felt by American. The word 'citizens' functions as a senser and 'the establishment' in target text functions as a phenomenon. The translator changes the point of view from source text by applying the modulation. The result is taking place the shift of process types. Passive meaning on verb 'dilindungi' is an attribute which explain the carrier 'pembangunan Amerika'. 
Table 15. ARP in Source Text

\begin{tabular}{ll}
\hline Data & Source Text \\
\hline 132.TS.ST & It is time to remember that old \\
& wisdom our soldiers will never \\
& forget: that whether we are black or \\
& brown or white, we all bleed the \\
& same red blood of patriots, we all \\
& enjoy the same glorious freedoms, \\
& and we all salute the same great \\
& American Flag.
\end{tabular}

Table 16. IRP in Target Text

\begin{tabular}{ll}
\hline Data & Target Text \\
\hline $132 . T S . T$ & Ini waktunya untuk mengingat \\
$\mathrm{T}$ & kembali bahwa kebijaksanaan para \\
& pasukan kita tidak akan pernah lupa; \\
& bahwa apakah kita memiliki warna \\
& kulit hitam atau cokelat atau putih \\
& tetapi kita semua menumpahkan \\
& warna darah merah yang sama, kita \\
& semua menikmati kebebasan yang \\
& sama dan memberi hormat kepada \\
& bendera Amerika yang sama. \\
\hline
\end{tabular}

Based on the data examples above, it can be seen from the source text that there is a copula 'is'. It is a marker that a clause is relational clause, especially attributive relational clause and the carrier is 'it'. It will be different in target text that there is no copula in Bahasa Indonesia in this case as target language. So, it is right that the translator applied the implicit technique. It causes the translation of process is shift. So, it results identifying relational process in source text to be attributive relational process in target text.

The findings of the research indicates that language was the mirror of their awareness by their reactions, cognitions, and perceptions, and also his linguistic acts of speaking and understanding and it clearly supports Halliday's theory (2014).

It seems that the research is supported by the SFL research done by (Sujono \& Wiratno, 2016) who study about the shift types of theme. The conclusion indicated that the shift theme is caused by the difficult to find out the theme structure in target language. Of course, the difficulties happen because of grammatical rule difference and difficulties in using the appropriate translation technique.

The findings of the research are also in line with Vinay and Darbelnet in (Newmark,
1988, p. 85) stated that modulation is a variation through a change of view point, of perspective and very often category of thought. In addition, Molina and Albir (2002) stated that modulation which is used by the translator can change the point of view, focus, or cognitive category in source text so it will be found the shift in translation.

The findings of the research are also similar with Susilowati (2010) and Mardiana (2014) who research the modulation and transposition in translation. The result of the research stated that the transposition and modulation used by the translator have some impacts to the quality of translation, consumers and the sales target because there were some meaning distortion which were not delivered from the source language. So, the meaning distortion has the impact to the mistakes in using the product which can make serious problem for the consumers.

Moreover, the study conducted by (Sumarli, 2017) stated that transposition and modulation can change the grammatical category which can cause the shift. If the translation used the transposition techniques appropriately, it would have not shift or meaning distortion can be avoided. But, if it is inappropriate in using transposition technique, it will cause meaning distortion. So, the translation result will influence the translation quality. This is relevant with (Catford, 1965, p. 73) stated that transposition is the shift. While Vinay and Darbelnet in (Newmark, 1988, p. 85) stated that shift is the result of the grammatical differences between source text and target text.

While, implicitation is opposite from explicitation. As Molina and Albir (2002) stated that explicitation is a translation technique by expressing the meaning directly or delivering the hidden message into target language. It also can cause the meaning shift dealing with the difference of grammatical rule between two languages. The purpose of using this technique is to ease the reader to understand the text. Again, the reduction technique is used to make information in the text to be dense from source language into target text. So, the effect of using this technique is some information decreased or even it will be lost in target language. 


\section{CONCLUSION}

Based on the research findings above can be concluded that there are 6 kinds of shift in Obama's speech translation. They are: a) identifying relational process into attributive relational process; b) mental process into mental behavioral process; c) material process into $\varnothing$ process; d) attributive relational process into attribute conflated with process; e) relational attributive into existential process; and f) material process into attribute conflated with the process. While the shift of translation caused by 3 translation techniques. They are implicitation, modulation, and transposition.

While, based on Trump's speech translation, it is obtained that there are 6 kinds of shift. They are: a) mental behavior process into attributive relational process; b) identifying relational process into attributive relational process; c) attributive relational process into attribute conflated with process; d) extra-causer process into attributive relational process into attribute conflated with process; e) material process into attributive relational process into attribute conflated with process; f) mental behavioral process into attribute conflated with process; g) identifying relational process into existential process. While the process shift caused by 4 translation techniques. They are: modulation, implicitation, explicitation, and reduction.
The study hopefully gives the contribution to enlighten on a particular aspect not only for translation but also extending to the systemic functional linguistics in several aspects that need to be researched. One thing which is interesting to be researched and complete this research is focusing on certain technique and its translation quality, for example, the study about literal translation or discursive creation.

Moreover, in the systemic functional linguistics, it can be researched in participants and circumstance element which are all above still under discussion and somewhat contentious. In addition, for the translator are expected to avoid some translation technique which causes the shift although it cannot change the meaning significantly.

However, starting from problems classification above, the breakdown of the specific verbal group in process types have not analyzed yet as well as its language style based on a verbal group. And, it hopefully will be beneficial to a partial re-evaluation of the outcomes. So, to strengthen and sharpener the study, the future researchers are expected want to research the specific item such as typology of verbal group pattern in process types of transitivity system. It can be political speech or opinion rubric in mass media or even it can be based on academic texts or students scientific writing. It will be interesting and give big benefit to compare the personal language style to build the opinion.

\section{REFERENCES}

Baker, M. (2011). In Other Words: A coursebook on translation, second edition. (M. Baker, Ed.), In Other Words: A coursebook on translation (Second). London: Routledge. https://doi.org/10.1075/target.24.1.19che

Bielsa, E., \& Bassnett, S. (2008). Translation in global news. Translation in Global News. https://doi.org/10.4324/9780203890011

Catford, J. C. (1965). A Linguistic Theory of Translation. Language and Language Learning. Retrieved from http://rahbar.iauq.ac.ir/assets/subdomains/rahbar/files/93/TheoriesOfTranslation/

Darani, L. H. (2014). Persuasive style and its realization through transitivity analysis: A SFL perspective. Procedia - Social and Behavioral Sciences. https://doi.org/10.1016/j.sbspro.2014.12.066

De Dios, T. (2013). ScienceDirect Exploring Transitivity Alternations across Dialects: A Preliminary 
Approach. Procedia - Social and Behavioral Sciences, 95, 425-430. https://doi.org/10.1016/j.sbspro.2013.10.665

Eggins, S. (2004). An Introduction to Systemic Functional Linguistics 2nd Edition.

Halliday, M. A. K., \& Matthiessen, C. M. I. M. (2014). Halliday's Introduction to Functional Grammar. https://doi.org/10.4324/9780203431269

Hatim, B., \& Munday, J. (2013). Translation An Advanced Resource Book. Journal of Chemical Information and Modeling (Vol. 53). https://doi.org/10.1017/CB09781107415324.004

He, Q., \& Wen, B. (2015). Reflections on the grammatical category of the than element in English comparative constructions: A corpus-based systemic functional approach. Ampersand. https://doi.org/10.1016/j.amper.2015.08.001

Hidayah, I. . (2013). Dampak pergeseran kelompok nomina dalam dua pidato kenegaraan presiden amerika serikat barrack obama dan terjemahannya terhadap kualitas terjemahan. Sebelas Maret University.

Hill-Madsen, A. (2014). Derivation and Transformation: Strategies in Lay-oriented Intralingual Translation, $308 . \quad$ Retrieved from http://pure.au.dk/portal/files/73870680/Dissertation_AageHM_final.pdf

Idrus, M. M., Nor, N. F. M., \& Ismail, I. S. (2014). Representing Action: Transitivity and Verb Processes in Malaysian and Singaporean Oral Proceedings Over Batu Puteh Island Issue. Procedia - Social and Behavioral Sciences. https://doi.org/10.1016/j.sbspro.2014.02.024

Ignatieva, N., \& Rodríguez-Vergara, D. (2011). Verbal processes in academic language in Spanish: exploring discourse genres within the systemic functional framework. https://doi.org/10.1186/s40554-015-0014-9

Isti 'anah, A., \& Id, A. A. (2014). Transitivity Analysis in Four Selected Opinions about Jakarta Governor Election, 14(2).

Mardiana, W. (2014). Teknik Transposisi dan Modulasi: Kesepadanan dan Pergeseran dalam Penerjemahan Cerpen Berjudul “My Beloved Edith.” Parole, 4(2), 120-130.

Matu, P. M. (2008). Transitivity as a tool for ideological analysis. Journal of Third World Studies; Spring, 25(1), 199-211.

Molina, L., \& Hurtado Albir, A. (2002). Translation Techniques Revisited: A Dynamic and Functionalist Approach. Meta: Journal Des Traducteurs. https://doi.org/10.7202/008033ar

Munday, J. (2009). Issues in translation studies. The Routledge companion to translation studies. Retrieved from http://www.google.com/books?hl=en\&lr=\&id=ictlRLq_pSsC\&oi=fnd\&pg=PA1\&dq=THE+ROU TLEDGECOMPANION+TO+TRANSLATION+STUDIES\&ots=9GSEtCp_w_\&sig=V2pS1szShe9dpw oSFOIeEWAOMPk

Nababan, M. (2012). Pengembangan model penilaian kualitas terjemahan. Kajian Linguistik Dan Sastra, 24(1), 39-57. Retrieved from https://publikasiilmiah.ums.ac.id/bitstream/handle/11617/2220/4. MANGATUR NABABAN.pdf;sequence $=1$

Newmark, P. (1988). A Textbook of Translation. Text. 
https://doi.org/10.1017/CB09781107415324.004

Nida, E.A and Taber, C. . (1982). The theory and practice of translation. Leiden: E.J. Brill.

Pramuditya, R. S. (2016). Analisis Dampak Teknik Penerjemahan terhadap Fungsi Experiential serta Nilai Keakuratan dan Keberterimaan Nominal Group dalam terjemahan Cerpen "The Adventure of the Veiled Lodger." Sebelas Maret University.

Purwaningsih, D. R. (2010). Analisis teknik dan kualitas terjemahanu unsur pre-modifier dalam kelompok nomina dalam novel the da vinci code. Sebelas Maret University.

Santosa, R. (2009). SFL and problems of equivalence in translation.

Seo, S. (2013). Hallidayean transitivity analysis: The Battle for Tripoli in the contrasting headlines of two national newspapers. Discourse and Society, 24(6), 774-791. https://doi.org/10.1177/0957926513503267

Spradley, J. P. (1980). Participant Observation. Harcourt Brace Jovanovich (Vol. 53). Orlando: Harcourt Brace Jovanich Inc. https://doi.org/10.1017/CB09781107415324.004

Sujono, A., \& Wiratno, T. (2016). A translation analysis of the multiple themes shift in rumi: a spiritual biography from english into indonesian (a systemic functional linguistics approach). In International Seminar Prasasti III: Current Research in Linguistics (pp. 92-98). Surakarta: Doctoral Linguistics Program of Sebelas Maret University.

Sumarli, F. (2017). Analisis terjemahan kolokasi budaya spesifik dalam novel the serpent's shadow dan terjemahannya bayangan sang ular karya rick riordan. Sebelas Maret University.

Toury, Gideon (2012). Descriptive translation studies - and beyond. Revised Edition. Philadelphia: John Benjamins Publishing Company. 